\title{
DIVINE ETERNITY AS TIMELESS PERFECTION
}

\section{EDMUND RUNGGALDIER}

University of Innsbruck

\begin{abstract}
Should we interpret God's eternity as mere everlastingness or as timelessness? We are still confronted with an ongoing debate between the two positions. That God is timeless or completely outside time might be called 'the classical view of divine eternity'. But this view can be interpreted in various ways. In reverting to some of Aquinas' texts I want to focus on the account of God's timelessness as a perfection. In trying to defend this view I will not offer any new arguments; I simply adopt the classical assessment of the meaning of the predicates we use when we speak about God. That God lives, loves, thinks, acts, etc., are claims which cannot be understood in the same way as when they are made of human persons.
\end{abstract}

\section{INTRODUCTION}

The classical doctrine of the peculiarity of our assertions about God relies on the distinction between the epistemic approach and the ontological dimension: What is prior in the order of knowledge need not be prior in the ontological order. We first see smoke and infer from it that something burns. In the realm of things, however, fire comes first, smoke being one of the effects of fire. Priority can be considered as merely epistemic, relative to our way of perceiving, thinking or getting knowledge (quoad nos) or on the ontological level (per se).

Scholastic scholars apply this distinction in the account of the meaning of God's predicates. One aspect of these predicates' meaning is brought about by our epistemic approach or by the way we learn to use a predicate, the other aspect pertains to the intended reference and thus to the peculiarity of the object to which we apply the predicate. The content of the statements about God can thus be considered as relative to our way of understanding, i.e., quoad nos, or relative to God's reality, i.e., per se. 
In his famous quaestio 13 on the semantics of God-talk, Aquinas distinguishes accordingly between a predicate's mode of signifying (modus significandi) and its referent (res significata), between the realm from which the meaning of an expression is taken and the realm of the application or reference of the same expression: that from which (ex quo) an expression is derived can differ from what it is intended to refer to ( $a d$ quod). ${ }^{1}$

This distinction might help to weight the arguments for and against the classical view of God's eternity. It certainly helps to understand why God's predicates connote quoad nos limitations and change in time, but exclude them per se. If God really is causa prima He cannot depend on any causa whatever, on any outer reality. He thus cannot suffer any limitations.

In this respect I share Tapp's concern with the relation between God's eternity and His infinity. God does not have any limits in his perfections and is thus infinite. Infinity, however, should not be interpreted in a mere quantitative sense, but in a deeper one. When God is called infinitely good, 'He is meant to be good in a very special, a perfect way, exceeding the usual spectrum of meanings of this word.'2 Similarly, - as Stump points out - to predicate of God that He is eternal is to predicate more than that He is timeless: ' ... a careful consideration of the texts [of Aquinas] shows that a-temporality alone does not exhaust eternality as Aquinas conceived of it ...' ${ }^{3}$

Abstract objects are a-temporal, but their being outside time is far from a perfection. Further, it cannot be said that they exist - if they exist at all - simultaneously with, before, or after any other entity. There is no simultaneity with other beings in time. If, however, eternity is understood as a kind of perfection, simultaneity is not excluded. We will see that the condition of being all-at-once (totum simul) is part of the explanans of the classical definition of eternity and that this all-atonce signifies perfection. Pasnau ${ }^{4}$ has strongly argued in favour of this classical understanding. In his terminology, a 'mereochronic' entity is one which partly exists at some instant in time, but also existed or will

\footnotetext{
${ }^{1}$... in significatione nominum, aliud est quandoque a quo imponitur nomen ad significandum, et id ad quod significandum nomen imponitur ... (S.Th. I ${ }^{\mathrm{a}} \mathrm{q} .13$ a. 2 ad 2).

${ }^{2}$ Christian Tapp, 'Eternity and Infinity', in God, Eternity, and Time, Christian Tapp and Edmund Runggaldier (eds) (Farnham: Ashgate, 2011), pp. 99-116 (p. 99).

${ }^{3}$ Eleonore Stump, Aquinas (London: Routledge, 2003), p. 131.

${ }^{4}$ Robert Pasnau, 'On Existing All at Once', in Tapp, God, Eternity, and Time, pp. 11-28.
} 
exist at other times. A 'holochronic' entity, by contrast, exists as a whole, all at once, for all of its existence. ${ }^{5}$ God is a-temporal in the sense of being 'holochronic' all at once.

Taken as a perfection God's timelessness does not exclude duration as such, even though it excludes duration in our human sense. As perfection it does not have a 'before' or an 'after', nor any kind of succession. It cannot be captured either by a B- series or by an A-series. As said, eternity in the classical sense does not exclude duration; on the contrary, it is the highest form of duration. In scholastic terminology the term 'duration' does not express the same meaning when predicated of created finite entities as when predicated of God. But from this it does not follow that the term 'duration' is used equivocally. The different meanings are similar or analogical. 'For Aquinas, analogical predication is the traditionally recognized solution to what otherwise would seem to be an insoluble dilemma.'

The special or analogical meaning of 'duration' and the other predicates predicated of God in the Thomist tradition is a consequence of the arguments of the quinquae viae, of the five ways to prove the existence of the causa prima. If one does identify the unmoved mover, the highest Aristotelian ousia, with the Christian God one is confronted with the thesis of God's simplicity and the consequences thereof. The predication of properties and actions of God must accordingly be interpreted in such a way that they do not contradict this identification of the Christian God with the causa prima. ${ }^{7}$

If God is the causa prima of all of reality, He cannot be contingent, i.e., He cannot depend on any entities whatsoever. He cannot be composed, not even of matter and form. ${ }^{8}$ Being absolutely simple He cannot have properties in the way contingent entities can have properties: He must be identical with any properties He has, and these properties cannot be but pure perfections (perfections purae), i.e. they cannot be affected by change in time. His simplicity excludes all properties implying finite determination or alteration.

\footnotetext{
${ }^{5}$ Pasnau, 'On Existing All at Once', p. 11.

${ }^{6}$ Stump, Aquinas, p. 146. See also Gregory P. Rocca, Speaking the Incomprehensible God (Washington D.C.: The Catholic University Press of America, 2004).

${ }^{7}$ See: S.Th. Ia, qq. 2-13.

${ }^{8}$ See also Suárez, 'Disputationes Metaphysicae', Opera Omnia 25/26 (Paris 1861), DM $50,3,9$.
} 
In this paper I thus will refer to the Thomist definition of eternity, then mention one of the main arguments against this classical view and revert to the analogical understanding of God's perfections based on the mentioned distinction between our human approach to them (quoad nos) and the intended reference (per se).

\section{THE THOMIST BOETHIAN DEFINITION}

Aquinas adopts and defends the Boethian definition of God's eternity as complete possession all at once of illimitable/interminable life (interminabilis vitae tota simul et perfecta possessio). ${ }^{9}$ In her comment Stump calls attention to the elements of the definiens, among them the conditions that an eternal God has illimitable life and that He has this life all at once (totum simul). ${ }^{10}$ Aquinas himself points to these two determining elements of the definiens: first, what is eternal is interminable, that is, has no beginning and no end; secondly, eternity has no succession, being simultaneously whole. ${ }^{11}$

Tapp sees in these elements of the definiens a correspondence with the thesis of God's infinity as 'outside the limits': “Interminablis vita", "illimitable life", excludes that the life of God [...] has ever had a beginning or an end. "Tota simul", being completely at once, excludes [...] the succession of temporal parts. "Perfecta", being "perfect", excludes the limitations of being that is received in something else and is thereby limited.' 12

We humans cannot imagine or visualize being in such an unbounded state all at once. But we can arrive at a conception of it by abstracting or negating certain aspects which are typical for our way of experiencing life. In trying to specify what eternity is, according to Aquinas, we cannot but begin with our own experience of change, one state coming after the other, i.e., by experiencing succession. By abstracting or negating change we put ourselves on the road to conceiving of eternity as duration lacking succession, being immutable duration.

${ }^{9}$ Ia q. 10 a. 1.

10 Stump, Aquinas, pp. 133f.

${ }^{11}$ Primo, ex hoc quod id quod est in aeternitate, est interminabile, idest principio et fine carens ... Secundo, per hoc quod ipsa aeternitas successione caret, tota simul existens. Ia q. 10 a. 1 c.

${ }^{12}$ Tapp, God, Eternity, and Time, p. 108. 
Aquinas believes that as humans we generally arrive at the idea of simple things via the negation of aspects of compounds. We cannot have direct knowledge e.g. of a geometrical point, but we can form an idea of it by negating its being extended or having parts. Aquinas explicitly claims that our intellect, which first apprehends compound things, cannot attain to the knowledge of simple things except by removing complexity. ${ }^{13}$ Thus, we obtain the idea of eternity by negating or abstracting the compound aspects of succession.

Since succession occurs in every movement, and one part comes after another - Aquinas unfolds - the fact that we reckon before and after in movement makes us apprehend time. Now in an unchanging thing, which is always the same, it makes no sense to assume a before or after. ${ }^{14}$ Likewise, the idea of eternity consists in apprehending the uniformity of what is completely outside of movement. ${ }^{15}$

Eternity follows immutability, as time follows change or movement. Hence - Aquinas argues - as God is supremely immutable, it supremely belongs to Him to be eternal. Nor is He only eternal rather, He is His own eternity. No other being, by contrast, is its own duration, as no other is its own being. ${ }^{16}$ Eternity truly and properly so called is in God alone. ${ }^{17}$ In his concise style Aquinas states that since God is maximally immutable He is to the highest degree eternal. ${ }^{18}$

\section{CAN GOD ACT?}

There is an ongoing debate on the Thomist classical conception. One objection is: If God is eternal in the defined sense how can He act? If actions are events and if events are changes, then one cannot consistently

${ }^{13}$... intellectus noster, qui primo apprehendit composita, in cognitionem simplicium pervenire non potest, nisi per remotionem compositionis. ( ${ }^{\mathrm{a}} \mathrm{q} .10 \mathrm{a} .1 \mathrm{ad} 1$ ).

${ }^{14}$ In eo autem quod caret motu, et semper eodem modo se habet, non est accipere prius et posterius. ( $\mathrm{I}^{\mathrm{a}} \mathrm{q} .10$ a. $\left.1 . \mathrm{c}\right)$.

15 ... ita in apprehensione uniformitatis eius quod est omnino extra motum, consistit ratio aeternitatis. ( $\mathrm{I}^{\mathrm{a}} \mathrm{q} .10$ a. $1 \mathrm{c}$ ).

${ }^{16}$... ratio aeternitatis consequitur immutabilitatem, sicut ratio temporis consequitur motum ... Unde, cum Deus sit maxime immutabilis, sibi maxime competit esse aeternum. Nec solum est aeternus, sed est sua aeternitas ... (Ia q. 10 a. 2 c).

${ }^{17} \mathrm{I}$ q $\mathrm{q} .10$ a. 3 c.

${ }_{18}$ Unde, cum Deus sit maxime immutabilis, sibi maxime competit esse aeternum. (I ${ }^{\mathrm{a}}$ q. 10 a. 2 c). 
say of God that He acts. One attempt at a way out, given by Leftow, questions the assumption that all events are changes and the assumption that necessarily, any event occurs before or after another event. ${ }^{19}$ And Tapp asks why it should not be possible to consistently assume that there be change without time. ${ }^{20}$

The Thomists, however, counter the objection by distinguishing between the meanings of those predications which imply change and those which can be combined with immutability. Saying of God that $\mathrm{He}$ acts and saying that $\mathrm{He}$ is timelessly eternal is not necessarily contradictory. Whether these statements contradict each other depends on the meaning of the statement that God acts.

The mode of signifying of 'acting' is taken from our experience of acting as human beings, but we intend to refer by the same expression to acts of a different agent, an agent having immutable duration. The modus significandi is taken from everyday life, but the res significata exceeds the realm of our experience. Due to His absolute simplicity God is per se essentially changeless, absolutely unable to change, but $\mathrm{He}$ is temporal relative to our ways of speaking, thinking and sensing.

For us it seems inconceivable that there be actions without succession. But that does not exclude the possibility of actions which per se do not imply a change in the agent. Because of the reasons supporting the thesis of God's simplicity and immutability it is plausible to assume that God's actions are per se without succession, even though we humans perceive of them quoad nos as actions in succession.

Aquinas argues forcefully for this already in the ScG: God's act of creation is per se neither motion nor change. ${ }^{21}$ Nevertheless, creation appears to us to be a kind of change. From the point of view of our way of understanding, creation appears to be an act with succession, in that our intellect grasps one and the same thing as not existing before and as existing afterwards. ${ }^{22}$

Furthermore, in any act of producing, our knowledge and experience of the doing come before the product itself. If creation were like a human

${ }^{19}$ Brian Leftow, 'Eternity', in A Companion to Philosophy of Religion (ed. by Philip L. Quinn and Charles Taliaferro) (Oxford: Blackwell, 1997), pp. 257-263 (p. 262).

${ }^{20}$ Tapp, God, Eternity, and Time, pp. $111 \mathrm{f}$.

${ }^{21}$ ScG. II, 17.

${ }^{22}$ Videtur tamen creatio esse mutatio quaedam secundum modum intelligendi tantum: inquantum scilicet intellectus noster accipit unam et eandem rem ut non existentem prius, et postea existentem. (ScG. II, 18). 
act there would be something preceding the thing created. But this would be contrary to the very idea of creation. If creation is ex nihilo, it cannot be preceded by something with the disposition to be realized or manifested by change. There is no prerequisite to creation; nor does God lack anything for accomplishing his action which he might have after the action. $^{23}$

As Eleonore Stump notes, a distinction must be made between acting in such a way that the action itself can be located in time, and acting in such a way that the effect of the action can be located in time. For an eternal being on Aquinas's view, only the first way of acting is impossible. That a divine action is not a successive event in time does not prevent God from causing effects located in time: 'Even though his actions cannot be located in time, he can bring about effects in time ...24 This applies to God's knowing as well: "God timelessly knows that the temporal entities are temporal; the mode of his knowing them is not the same as the mode of their existence, nor need it to be..25 And Schärtl warns of slipping from 'God is eternally aware of $\mathrm{x}$ ' to 'For God $\mathrm{x}$ is eternal. ${ }^{26}$

Stump defends the notion of a-temporal duration, she grants, however, a certain apparent incoherence, but attributes this to the experience of our own duration. For us the past no longer exists, the future does not exist yet, and the present is evanescent. For Aquinas genuine duration cannot be like that; it has to be fully realized duration and such fully realized duration must be a-temporal duration: 'Atemporal duration [...] is duration none of which is not - none of which is absent (and hence future) or flowed away (and hence past). On this way of thinking about time and eternity, eternity, not time, is the mode of existence that admits of fully realized duration. ${ }^{27}$

${ }^{23}$ In creatione autem nihil praeexigitur ex parte materiae: nec aliquid deest agenti ad agendum quod postea per motum ei adveniat, cum sit immobilis, ut in primo huius operis ostensum est. (ScG. II, 19).

${ }^{24}$ Stump, Aquinas, p. 151.

${ }^{25}$ William Hasker, 'God, Time and Knowledge', in Philosophy of Religion, Eleonore Stump and Michael J. Murray (eds) (Oxford: Oxford University Press, 1999), pp. 53-57 (p. 56).

${ }^{26}$ Thomas Schärtl, 'Why we need God's eternity', in Tapp, God, Eternity, and Time, pp. 47-62 (p. 61).

${ }^{27}$ Stump, Aquinas, p. 145. 


\section{UNCREATED AND CREATED DURATION}

In scholastic philosophy it is commonplace to distinguish between uncreated and created duration. The former is infinite and proper to God; the latter is finite and can include the duration of incorruptible, everlasting spiritual entities, or of elapsing corporeal things. Created duration is successive like motion and change, whereas uncreated duration is all at once (tota simul), without any succession. God's eternity is thus infinite duration, lacking any before and after: Dicitur Aeternitas Duratio Dei infinita: Itaque; non habens prius, nec posterius. ${ }^{28}$

Suárez too clearly distinguishes between uncreated and created duration. ${ }^{29}$ The uncreated duration is proper to God. It is a real perfection. Those who deny its reality do so because they take it as essentially combined with succession. This is our human way to conceive of the co-existence of things in their duration. But God does not depend on any external reality whatsoever.

God has the most excellent kind of eternity, affecting not only His being, but the whole of His reality. His kind of eternity includes all perfections, all acts, and all inner operations. Since God is identical with the perfections of being, He is identical with the fullness of duration. His eternity is full duration of His operations as well. This kind of eternal duration differs from any other kind of duration which is linked to succession - be it permanent, immutable, or indivisible. ${ }^{30}$

It is thus cogent to assume that in God there is neither past nor future. That He has neither past nor future applies not only to his being, but to his knowledge, to His love, and to all other perfections as well. If an entity is eternal in the full sense, everything in it has to endure through true eternity, such that nothing can pass away or supervene; everything has to remain for ever. ${ }^{31}$

Following Aquinas, Suárez does not exclude however that in religious language we speak and conceive of God's eternity quoad nos, i.e. according to our way of sensing, as if it were everlastingness. We then speak as if there were succession and thus past and future in God. We say

${ }^{28}$ Rudolph Goclenius, Lexicon Philosophicum, 196, 561.

${ }^{29}$ DM 50, 3, 1 .

${ }^{30}$ Ac proinde recte discernitur aeternitas ab omni alia duratione, quae, quantumvis permanens aut immutabilis vel indivisibilis videatur, successionem habet adiunctam ... (DM 50, 3, 10).

${ }^{31} \mathrm{Nam}$ si res vere aeterna est, quidquid in ea est per veram aeternitatem durat; et ideo nihil horum transire potest nec succedere in ipsa, sed semper manere. (DM 50, 3, 11). 
of God that He always was, that He always is and that He always will be, because we conceive of an eternal entity not as it is in itself, but according to our way of perceiving. ${ }^{32}$

We human beings conceive of eternity as being infinitely extended or as a kind of everlasting stream. But in God's reality there is no flux, no flowing. This is only an extrinsic way of speaking which is due to our existence in time and which accords with our way of perceiving and thinking. ${ }^{33}$ To say that something is past is to say that it no longer exists; and to say that it is future, that it does not exist yet. But God's perfection excludes that $\mathrm{He}$ ever had things that He no longer has and that He will have things he does not yet have. This applies also to His knowledge, love, and all of his proper and internal acts or perfections. ${ }^{34}$

\section{NO THIRD WAY}

The Thomist and scholastic strategy of distinguishing between per se and quoad nos should not be confused with the so-called third way, proposed by Padgett. ${ }^{35}$ Padgett tries to avoid the main objections against God's eternity conceived as absolute timelessness. God should accordingly be timeless relative to the created space-time cosmos, but also in some ways temporal. God is the Lord of time, not its prisoner.

The intuition behind Padgett's view is, 'God is still temporal in some sense: God is immutable in essence, but changing in inter-relationship with the world and with us [...] For this reason there are intervals within God's life, but those intervals have no specific or intrinsic temporal measure. ${ }^{36}$ One should thus distinguish between physical time, which began with the creation of the universe, and metaphysical time which

${ }^{32}$ Dicimus enim et Deum fuisse semper et esse et futurum esse, quia nos non concipimus rem aeternam prout in se est, sed nostro modo. (DM 50, 3, 12).

${ }^{33}$... in ipsa aeternitate Dei nullus est fluxus, et consequenter nec praeteritum aut futurum, sed per denominationem extrinsecam ex coexistentia nostri temporis, iuxta modum concipiendi nostrum. (DM 50, 3, 12).

${ }^{34}$... intelligendum est de scientia, amore et de aliis propriis et internis actibus seu perfectionibus Dei. (DM 50, 3, 12).

${ }^{35}$ Alan G. Padgett, 'The Difference Creation Makes: Relative Timelessness Reconsidered', in Tapp God, Eternity, and Time, pp. 117-125; 'Eternity', in The Routledge Companion to Philosophy of Religion, Chad Meister and Paul Copan (eds) (London/New York: Routledge, 2007), pp. 287-295.

${ }^{36}$ Padgett, 'The Difference Creation Makes', p. 118. 
can go on without change and without laws of nature and which had no beginning.

Padgett's concern seems to be to defend the possibility of God's performing real actions. For this he assumes a kind of succession on the part of the divine and says that we need a theory of direct divine action according to which 'God acts upon and interacts with temporal things at moments which do not and cannot all exist at once. ${ }^{37}$ God might have been immutable before creation, but we have to think of him as having been capable of change in virtue of his creating something: 'For all eternity past, even before all creation, God is at least capable of changing in order to make reality $b e$ in the first place. ${ }^{38}$

On the other hand, the third way maintains the view that even after creation God is in a certain sense outside time: He always transcends space and time. None of the qualifications of physical time makes sense when applied to God's infinite and eternal being.

Padgett explicitly says: 'Thus I argue against Craig and Swinburne that some aspects of God's relative timelessness before creation continue to apply even when God changes with a dynamic creation. We might say that God becomes more robustly temporal after creation by becoming a changing being. But God for eternity past was always temporal in a bare metaphysical sense, since God was always capable of change. ${ }^{39}$

According to the so-called third way, God is temporal in a minimalist sense of the word, transcending the limitations we associate with ordinary finite temporal beings. God is both temporal and yet also relatively timeless. This diverges from the classical standpoint: God is per se timeless, but quoad nos as if He had duration with succession.

\section{THE ANALOGICAL SENSE OF GOD'S PREDICATES}

What is special about the expressions referring to God? Let us look at the quaestio 13 'De nominibus Dei'. Aquinas sticks to the Aristotelian semantics: Words do not refer directly to the things signified, but refer only via the conceptions of the speakers. The speaker's intellectual conception is a means or a medium for the reference of the words he uses. $^{40}$

\footnotetext{
${ }^{37}$ Padgett, 'The Difference Creation Makes', p. 121.

${ }^{38}$ Padgett, 'The Difference Creation Makes', p. 121.

${ }^{39}$ Padgett, 'Eternity', p. 294.
} 
Reference is thus at least a three-place relation between the word, the speaker grasping the referent, and the referent. Without the speakers' conceptions words would not have any reference. It is because of speakers' intentions, ideas, and notions that the words they use have reference. Speakers use expressions in order to refer to things or state of affairs insofar as they form an idea (ratio) or a representation of them. In the ideal case speakers grasp the essence of the referent. But even speakers who lack an adequate conception of the referent might still be successful in their referring acts.

The Aristotelian semantics allows for the assumption that expressions with differing meanings, linked to different conceptions and ideas, can nonetheless have the same referent. The ideas expressed by or likened to the expressions can be more or less adequate, but these ideas are viable as long as they indicate how to refer to the intended referent. Aquinas thus states that we can give a name to anything insofar as we can understand or grasp it. ${ }^{41}$

Reference to human beings, for example, is guaranteed by the knowledge we have of the essence of 'homo'. In the case of God things turn out to be tricky because we cannot know what the divine essence is. But our referring acts might nonetheless be successful because of other conceptions we have of Him. These are inadequate but do not necessarily hinder the reference. God can be named by us, although not in such a way that the name signifying Him expresses the divine essence.

In his study on the peculiarity of God-talk, Gregory P. Rocca shows that even in the case of expressions referring to absolute perfections, there is always a creaturely connotation (consignificatio) insofar as our manner of understanding the perfection is necessarily influenced by our experience of material reality. ${ }^{42}$

And what should we say about the relation between God and His creatures? Is it a real relation? Aquinas accounts for the relation between God and the creatures as a mixed asymmetric relation and thus does not exclude the possibility of predicating attributes which import change, but real change can occur only in creatures - not in God. One can say

\footnotetext{
${ }^{40}$ Et sic patet quod voces referuntur ad res significandas, mediante conceptione intellectus. ( ${ }^{\mathrm{a}} \mathrm{q} .13$ a. $\left.1 \mathrm{c}\right)$.

${ }^{41}$ Secundum igitur quod aliquid a nobis intellectu cognosci potest, sic a nobis potest nominari. I ${ }^{\mathrm{a}}$ q. 13 a. $1 \mathrm{c}$.

${ }^{42}$ Gregory P. Rocca, Speaking the Incomprehensible God, p. 343.
} 
that the relation between God and the creatures is real insofar as the creatures really refer to God. ${ }^{43}$

Aquinas conceives of such an asymmetric relation as mixed, i.e., real in one relatum and unreal (rationis tantum) in the other. For instance, a relation between a sensing and knowing subject on the one hand and the sensed and known thing on the other is grounded in real change in the subject but not in the intentional object. One can say that the relation is real inasmuch as the subject is intentionally directed toward the intentional object, whereas it is not real considered from the side of this object. ${ }^{44}$

In order to illustrate this asymmetric relation Aquinas refers to a further example: We can say that somebody is at the right of a column, but that does not imply that we predicate of the column a special attribute. Aquinas explains, 'standing on the right of the column' is not grounded in the column, but in the person. ${ }^{45}$

What are the consequences of this argument? It is possible to say of God that He is Creator, Lord, and Redeemer, predicates which import a relation to the creatures and thus to time, but these predications imply merely that the creatures depend on God but not that God depends on His creatures. ${ }^{46}$ To predicate of God that he is Lord (dominus) is to say something true. He really is the Lord because the creatures really are subject to him. Since the relation of subjection is real in the creature, it follows that God is Lord not merely in idea, but also in reality. ${ }^{47}$

Aquinas concedes that it makes sense to say of God that He was not Lord before there were any creatures. However, one can accept this without having to assume any real change in God himself. It is similar to

${ }^{43} \mathrm{I}^{\mathrm{a}} \mathrm{q} .13$ a. 7 c.

${ }^{44}$ Sicut sensus et scientia referuntur ad sensibile et scibile, quae quidem, inquantum sunt res quaedam in esse naturali existentes, sunt extra ordinem esse sensibilis et intelligibilis, et ideo in scientia quidem et sensu est relatio realis, secundum quod ordinantur ad sciendum vel sentiendum res; sed res ipsae in se consideratae, sunt extra ordinem huiusmodi. Unde in eis non est aliqua relatio realiter ad scientiam et sensum; sed secundum rationem tantum, inquantum intellectus apprehendit ea ut terminos relationum scientiae et sensus. ( ${ }^{\text {a }} \mathrm{q}$. 13 a. 7 c).

${ }^{45}$ Et similiter dextrum non dicitur de columna, nisi inquantum ponitur animali ad dextram, unde huiusmodi relatio non est realiter in columna, sed in animali. (I ${ }^{\text {a }} \mathrm{q} .13$ a. 7 c).

${ }^{46} \mathrm{I}^{\text {a }}$ q. 13 a. 7 ad 2.

${ }^{47}$... cum relatio subiectionis realiter sit in creatura, sequitur quod Deus non secundum rationem tantum, sed realiter sit dominus. Eo enim modo dicitur dominus, quo creatura ei subiecta est. (Ia q. 13 a. 7 ad 5). 
the case of unknown things which become known. When the potentially known becomes actually known it does not undergo any real change. The change only affects the knower. Still, because the meaning of 'Lord' includes the idea of a servant and vice versa, these two relative terms, 'Lord' and 'servant', are simultaneous by nature. Hence, God was not 'Lord' until He had a servant subject to Himself. ${ }^{48}$

There is thus nothing to prevent expressions which ascribe a relation to the creature from being predicated of God temporally, not by reason of any change in Him, but by reason of the change of the creature. ${ }^{49}$

\section{CONCLUSION}

God's eternity in the classical sense is not only timelessness, but a perfection (totum simul). Taken as a positive attribute it does not exclude duration as such, even though it excludes duration in our human sense having a 'before' and 'after'. This classical conception is consistent with the thesis that God is infinitely perfect and simple, which is a consequence of the thesis that God is causa prima of the whole of reality.

However, if one adheres to this classical view one is confronted with the objection that such an eternal God cannot act and is no person. But saying that God acts and saying that $\mathrm{He}$ has immutable duration is no contradiction as long as we distinguish between the modus significandi and the res significata. The mode of signifying of 'acting' is taken from our experience of acting as humans beings in time, but we intend to refer by the same expression to the acts of a different agent, an agent with immutable duration. The res significata, i.e., the intended referent, exceeds our experience: that from which (ex quo) an expression is derived can differ from what it is intended to refer to (ad quod). ${ }^{50}$

48 ... quia tamen in significatione domini clauditur quod habeat servum, et e converso, ista duo relativa, dominus et servus, sunt simul natura. Unde Deus non fuit dominus, antequam haberet creaturam sibi subiectam. (Ia q. 13 a. 7 ad 6).

${ }^{49}$ Cum igitur Deus sit extra totum ordinem creaturae, et omnes creaturae ordinentur ad ipsum, et non e converso, manifestum est quod creaturae realiter referuntur ad ipsum Deum; sed in Deo non est aliqua realis relatio eius ad creaturas, sed secundum rationem tantum, inquantum creaturae referuntur ad ipsum. Et sic nihil prohibet huiusmodi nomina importantia relationem ad creaturam, praedicari de Deo ex tempore, non propter aliquam mutationem ipsius, sed propter creaturae mutationem. ( ${ }^{\text {a }} \mathrm{q} .13$ a. 7 c).

50 ... in significatione nominum, aliud est quandoque a quo imponitur nomen ad significandum, et id ad quod significandum nomen imponitur ... ( ${ }^{\text {a }}$ q. 13 a. 2 ad 2). 
The main arguments against the classical view thus lose some of the force attributed to them. 